\title{
SOME ISLAMIC PATTERN IN RELATION TO FOOD AND WATER HYGIENE
}

\author{
Mahdi Fakhar \\ Department of Parasitology and Mycology, Mazandaran University of Medical Sciences, Sari, Iran \\ mahdi53@yahoo.com \\ Morteza Darabinia \\ Department of Islamic Studies, Faculty of Medicine, Mazandaran University of Medical Sciences, \\ Sari, Iran \\ m.darabinia@gmail.com \\ Mahboobe Montazeri \\ PhD student of Department of Parasitology, Faculty of Medicine, Mazandaran University of Medical \\ Sciences, Sari, Iran
}

\begin{abstract}
Islam is the most complete religion that pays special attention to human beings lifestyle. As Islam gives importance degree to spiritual and moral development of human beings, it equally emphasizes on body health and wholesome nutrition and guarantees human health with its life-giving commandments. In this study, we survey the importance of food safety on human beings physical and mental health, from the perspective of the Quran and quotes of Imams . The authors of this study gathered and surveyed the required information concerning food safety by referring to the Quran, Sahifa Sajjadiya, Nahj al-Balagha and by studying scientific texts. Multiple commandments concerning human nutrition and health were obtained by analysing gathered information. These instructions were also obtained by comparing religious and scientific resources. The results of the study of Islamic texts show that the most accurate commandments about the quality of water and food and human being nutrition have been gathered in Islam and human being will be immunized against many diseases if he applies these commandments in life. This study- according to Islam commandments- shows that not only Muslims have been prevented from using substances that are harmful to the body, but also be emphasized on human proper nutrition.
\end{abstract}

Keywords: Food hygiene, Water hygiene, Islamic patterns, Health

\section{INTRODUCTION}

In Islamic texts, there are many subjects about food and nutrition, but not all were studied scientifically. That's why some people may think that Islam doesn't pay sufficient attention to nutrition issue or pays attention only to primary topics which lapse in time and are not applicable anymore, while today Halal food standard has become a global brand. Contemplation of verses and Hadith guarantee the access to the secrets of creation in excellent system that not made in vain. The statements of Imams are full of principles and rules that guide the thinker well to know God's blessings and use them (Darabinia et al 2016).

1400 years ago, in Islamic texts, especially in the prayers of Imam Sajjad and Nahj al-Balagha, there were numerous references to health and hygiene. In the book Nahj al-Balagha that contains the Sermons of Imam Ali, the term of "wholesomeness" and its derived terms were repeated at least 10 times, term of "Bless" at least 12 times, and the word of "Health" has been repeated at least 14 times. That shows the importance of health and hygiene from the perspective of Imams. 
According to Arabic dictionaries, the term of "Bless" is equivalent to health and well-being. And the meaning of this word is more general than the word "wholesomeness" which is the opposite of being sick. In dictionaries, the word "Bless" is also used as "forgiveness" which in fact refers to the spiritual dimension (Nahj al-Balagha, Asadi Pooya 1996), but in our article, it is used as a synonym of health. As defined by the World Health Organization (WHO) health is the complete physical, spiritual and social comfort and not merely the absence of disease and disability; Islam mentioned this point 14 centuries ago. For example, in $23^{\text {th }}$ prayer of the book "Sahifa Sajjadiya" the physical and spiritual aspects of human health are both mentioned. In the first prayer, Imam Sajjad thanks God for feeding man with healthy foods and in the $27^{\text {th }}$ prayer, Imam mentioned waterborne diseases (Cholera) and food borne illness (Sahifa Sajjadiya, Asadi Pooya et al 2000).

The Holy Quran expresses the most general commandments about nutrition and health of human and saw: Of course man must be careful of food and nutrition (Sure Abase, verse 24) and states elsewhere: People of faith, if you are worshipper, eat from healthy food that we have given to you and give thanks to God, if you are worshiper (Sure Baqarah, verse 172).

Generally, from the perspective of Islam, any food that is harmful to body is Haram and prohibited. So according to jurists sentence, many foods that are not mentioned in the Quran and Tradition but are harmful to humans, are Haram and forbidden. In addition, in hygienic topics, Islam, as a simile, considers dirt and microbes as Devil and it considers hygiene and cleanness as light and mercy (Paknejad 2014, Norani 1990).

Imam Reza states: God did not make Halal any foods or drinks unless they were in the interest of human and did not make them Haram and forbidden unless they caused harm, death and corruption. For example, consumption of some fruits and vegetables is considered as desirable, because they fortify the teeth or they have positive effect on stomach function (Teb Al-Reza).

Also in $172^{\text {th }}$ verse of Sure Baqarah, God states: People of faith, eat from clean and Halal nutriments that we have given to you. And in verse 173 of Sure Baqarah, God saw: God made Haram the carrion, blood, pork meat and all animals slaughtered without mentioning the name of God. The consumption of pork meat, alcoholic beverages and carrion are the examples of forbidden consumption in the Quran (Quran, Sure Baqarah, verses 172 \& 173).

The Holy prophet Muhammad considered the observance of cleanness and hygiene before and after eating, as a condition of blessing of food. That shows the importance of hygiene standards while eating and its positive and useful effects from the perspective of the Prophet of Islam (Teb al-Nabi).

In Islamic texts, there are many topics about water and food hygiene that are considered suitable for the past time and not applicable from the perspective of some people. In this study, by referring to the Quran, accurate interpretations, quotes of Imams and other Islamic resources (Sahifa Sajjadiya and Nahj Al-Balagha) and by studying scientific texts, we gathered and studied different information concerning the importance of food safety in different dimensions on mental and physical health. The results of this study are gathered in several parts of this article: The Infected surfaces, predisposing factors for the proliferation of microbes, microbial toxin, food and water incompatibilities and meat hygiene. These parts contain the most minor health issues in accordance with the community's level of that time understanding.

\section{SOME INFECTED SURFACES}

Imam Ali saw: Don't drink water from the hole created on water bowl or from the side of the cup handle cause Devil (today means microbes) sits on the hole or handle. Imam Baqer also has prohibited drinking water from the side of the cup handle or broken part of pot cause these are the places of microbes (Abdullah Shobbar). Prophet of Islam saw: Don't spill the trash behind the door since that become the place of Devil (or microbes). (Teb Al-Nabi) 


\section{PREDISPOSING FACTOR FOR THE PROLIFERATION OF BACTERIA, IN PARTICULAR SOME FUNGI}

Imam Ali saw: Devil (or microbes) tends to live in humid, greasy and dark places (Norani 1990, Abdullah Shobbar). Prophet of Islam saw: Do not pass night with greasy hands; otherwise, you may blame yourself if Devil (or microbe) hurts you (Teb Al-Nabi).

\section{MOCROBIA TOXIN}

Imam Sadiq saw: Cover the dish cause Devil (or microbes) eats from the dish and releases saliva (or toxin) on it (Teb Al-Sadiq)

\section{FOOD INCOMPATIBILITIES}

Imam Reza saw: Avoid eating both fish and eggs cause the combinations of these two foods in stomach develops gastrointestinal discomfort and causes Gout, Colic, Haemorrhoid and toothache (Teb Al-Reza)

\section{FOOD TOXINS}

Imam Reza considers food toxins as the reason of a group of diseases with unknown causes (Ibid).

\section{WATER HYGIENE}

The followings quotes come from Imams, they are related to water hygiene:

Boiled water is beneficial for all things and is not harmful to anything.

Avoid drinking water after eating fruits or greasy food (Drinking water after eating greasy food causes acid reflux).

Do not bathe with subterranean water or water of well cause these waters are also consumed by the others.

During the digging of well, make a distance between water of well and wastewater.

Your drinking water should be white (clear) and lightweight. The best water to drink is the water that the first rays of the sun in summer, pass over it.

Avoid drinking salt water with heavy volume or abundant in minerals. Drinking salt water causes constipation.

Rain water is light, soft, tasty and useful as long as it is not remained in a hole (Sahifa Sajjadiya, Paknejad 2014, Teb Al-Reza, Teb Al-Nabi, Teb Al-Sadiq).

\section{MEAT HYGIENE}

Prophet of Islam saw: Raw meat should not be eaten till the fire or the sun -prepared meat with solar heat- changes it.

Eating the meat that is dried in the shade is prohibited.

Eating the meat of a bird that eats uncleanness is prohibited unless it eats only healthy and clean food for a specified period of time.

In Islam, eating the meat of some animals such as pork, canine, rabbit, crow, birds with claws, and also some parts of animals with Halal meat like Testes, vulva, uterus, spleen, spinal cord, pituitary and the blood is forbidden.

Consumption of Carrion meat is also prohibited. A fish that died in the water should not be eaten.

According to Islam emphasis on prohibition of pork consumption, it is necessary to mention some points about it. The holy Quran cited directly the prohibition of the consumption of pork in four Sure of Maedeh verse 3, Nahl verse 115, Baqarah verse 173 and Anam verse 145. The prohibition of consumption of pork is also cited in other religions like Judaism and Christianity (Paknejad 2014).

According to the studies of medical science researchers, the consumption of pork meat could cause several infectious diseases such as parasitic diseases including protozoan or helminth diseases in human (Ibid, Eslami 2006).

Therefore, diseases like eye and brain Cysticercoids transmitted through the consumption of raw or half-cooked meat of pork have low prevalence in Islamic countries cause pigs are not raised in these countries and these animals live just as wild boars in forest areas (Djurković-Djaković et al 2013).

Prohibition of pork consumption is not only due to disease transmission cause many diseases are transmitted to human by consumption of Halal meat animals like cows, sheep and birds but Islam has never prohibited the consumption of the meat of these animals. So the issue of prohibition of porcine meat consumption is beyond the transmission of disease and damage to the human body and according to Islamic texts, it seems that social, mental and psychological problems and unethical behaviour are also the factors of prohibition of consumption of porcine meat (Spotin et al 2014). Also the studies of 
researchers show that consumption of the meat of each animal, passes some traits of the animal to the consumer and this can affect a person's behaviour (Sakr 1971).

On the other hand, the attention of Islam to human dignity makes it prevent people from consuming the meat of predatory and feces eating animals.

\section{HEALTH TIPS OF IMAM REZA}

Eating kidney and internal organs of sheep (tripe, abomasum) is not correct because it is harmful to the bladder.

Eating meat that is not cooked properly creates worm in the stomach. Here Imam refers to the prevention of diseases causes by Taenia Saginata or measles.

Avoid overusing of beef and hunted meat. Imam may have paid attention to the risks of red meat for health.

Abstaining from eating slow digesting foods and toxic substances such as alcohol, tobacco, foods irritating the stomach and observance of food consuming time.

Those who don't want to suffer from stomach pain don't drink water while eating. Drinking water while eating weakens the stomach and causes indigestion. Today, it has been confirmed that this causes acid reflux.

Avoid eating too much onions cause high consumption of onions decrease the happiness of the face.

Do not eat too much boiled eggs; it causes shortness of breath and flatulence problems.

Don't drink cool water after eating sweets or hot foods cause it's harmful to your teeth.

If you want to prevent your tonsils from growing, gargle vinegar after eating sweets.

In trip, use fresh meat without fat, use also vinegar and verjuice.

Honey with pungent smell, or honey that weakens the body or burn tongue are not good to use.

Do not eat citron at night because it has undesirable effect on eyes.

\section{SOME OF EATING AND DRINKING ADVICE IN ISLAM}

Avoid eating hot food.

Avoid blowing on foods and drinks.

Avoid eating and drinking with left hand.

Take off your shoes while eating.

Avoid drinking salt water that contains sulphur; avoid drinking water with changed color and taste.

Drink water during the day while you are standing up and during the night while you are sitting.

Avoid eating leftover of animal feed.

Wash your hands before and after eating.

Use fresh vegetables while eating. The prophet of Islam considers the exclusion of devil (or microbes) as an important property of fresh herbs and vegetables.

Avoid cutting bread with knife.

9.11. Use a little amount of salt at the beginning and at the end of meal. This neutralizes the acidic environment of the mouth, keeps teeth healthy and helps the stomach to digest the food (Norani 1990, Kordafshari 2015).

\section{CONCLUSION}

Islamic instructions are based on human beings' nature and all what we see in Islamic texts about Halal (lawful) and Haram (unlawful) are based on human real interest. The holy Quran provides best commandments concerning food safety. It provides instructions about Halal food by taking into account all aspects of health, quality and safety. Implementation of such standards is subject to understanding the Quran, the acquisition of modern knowledge, education and practical promotion of Halal (lawful) and Haram (unlawful) culture, quality and safety assurance programs and going towards the production of organic products.

The doctrine of Islam has forbidden the evil and considers cleanness and health as Halal and lawful and provides solutions to achieve balance in life. Islam is a religion that provides solutions to strengthen and calm the spirit of the people in the society. It also provides commandments for nutrition and health of people in individual and social aspects. So the followers of this religion feel its 
practical and spiritual role in their personal life. They never feel themselves away from the source of God's grace.

Islam expresses most hygienic issues as Obligatory, Prohibited, Recommended and Detestable. For example, eating unclean and evil things such as meat of carrion, Haram meat animals, alcohol and other harmful things to the mind and damaging to health are Haram. On the other hand, many hygienic topics that have important roles in people's life are stated as obligatory or recommended. For example, the conditions of prayer are the purification of body and clothes, and ablution are obligatory for prayer. Also in ablution, washing inside the nose and mouth and brushing the teeth are recommended. One of the reasons of attention of Islam towards hygienic topics especially water and food health is to prevent the transmission of diseases and food poisoning caused by consuming unhealthy food. As it is proven today, unhealthy food has important role in the transmission of many parasitic diseases such as measles, lung flukes, liver flukes, fish tapeworm, amoebic dysentery, and intestinal infections such as gastroenteritis, bacillus dysentery, cholera, typhoid, jaundice and infectious hepatitis. In the end, since many progressive Islamic rules on hygiene remain unknown, so research and scientific study on these rules could bring useful outcome for humanity, therefore it is suggested that further research would be conducted for finding the relationship between Islamic medicine and modern medicine and promoting health issues that are emphasized in Islam.

\section{REFERENCES}

Abdullah Shobbar. Teb Al- aeme. Translated by Pasandide A.Tehran.

Alipour F, Mahdavi F (2014). Halal (lawful) and Tayyib (clean) are the highest standards of food hygiene in the Quran. Islam Health J. 1(2): 41-50.

Asadi Poya A (1996). A brief about Medicine and Health in Nahjol balaghe. Second Edition, Shiraz: Kooshamehr.

Asadi poya A ,Shahriari M. Panjeshahin M (2000). Brief conceptions about Medicine and Health in Sahifa Sajjadiya. First Edition, Shiraz: Medical University publisher.

Darabinia, M., Sadeghzadeh, N., Gorji, A. M. H., \& Chabra, A. (2016). Medicinal properties of pomegranate in Quran and Islamic Traditions (Hadith). International Journal of Humanities and Cultural Studies (IJHCS), 1(1), 1591-1601.

Djurković-Djaković O, Bobić B, Nikolić A, Klun I, Dupouy-Camet J (2013). Pork as a source of human parasitic infection. Clin Microbiol Infect, 19(7):586-94.

Eslami A (2006). Veterinary Helminthology, Vol 2,Cestodes,Tehran: University press.

Kordafshari Gh, Mohammadi Kenari H, Esmaeili S, Moghimi M (2015).Nutrition in Iranian and Islamic Medicine. $44^{\text {th }}$ Issue, $2{ }^{\text {th }}$. Qom: Nasle Nikan press.

Nahjolbalaghe, Translated in Persian by Dashti M (2000), Qom: Parsayan.

Norani M (1990). Islamic Health, Vol 1, Tehran: Maktabe Ahlebeit publications, p 302.

Paknejad S R (2014). The first University and last of the Prophet, Vol 10, Tehran: Eslamieh press.

Quran, H. Translated by Naser Makarem Shirazi (2008). Tehran: Karafarinan-e Farhang va Honar.

Sahifa Sajjadiya, Translated in Persian by Ansarian H. (1993), Tehran: Pyame Azadi publisher.

Sakr AH (1971). Dietary Regulations and Food Habits of Muslims. J Am Diet Assoc, 58(2): 123-126.

Spotin A, Rouhani S, Parvizi P, Shahbazi A, Najafian J, Zaman J, Ahmadpour E, A Bordbar A (2014). A survey of the effects of pork consumption on human physical and mental health based on Islamic narratives and medical parasitology. Religion Health, 2(1) :61- 68.

Teb Al- reza. Translated by Kazemi K (1992), Tehran: Foad publications.

Teb Al- sadiq. Translated by Fazel J (2005). Tehran: Doyaye Ketab publications.

Teb Al-nabi. Translated by Fazel J (2010), Tehran: Doyaye Ketab publications. 